\title{
Walter Benjamim e a Escola Nacional Florestan Fernandes (ENFF) do MST: aproximações e cruzamentos
}

\author{
Micharlles Lopes Paz \\ Universidade Estadual do Ceará - UECE \\ Prof. Dr. David Barbosa Oliveira \\ Universidade Estadual do Ceará - UECE \\ https://revistas.uece.br/index.php/inovacaotecnologiasocial/article/view/4766
}

\section{Resumo}

O objetivo precípuo do corrente artigo é tecer aproximações entre o pensamento revolucionário-romântico do filósofo Walter Benjamim com a experiência da Escola Nacional Florestan Fernandes (ENFF) do MST. De que modo este pensador judeu-alemão que viveu as tensões decorrentes da primeira metade do século XX teria relação com esta escola rebelde surgida nos albores do século XXI? Há possibilidade de conexões neurais e coronárias entre ambos? Qual seria o enriquecimento teórico-prático deste achegamento? Não se trata de encaixar a fórceps a teoria benjaminiana na experiência da ENFF, mas sim de historiar um pouco pontos de intercessão entre seus sonhos e receios, respeitando o lapso temporal que os separa e as singularidades de cada contexto histórico. Trata-se de um bate-bola entre visões de mundo que se abraçam, de idéias e ideais convergentes que alumiam pontos da inteligibilidade histórica de nossos dramas e expectativas atuais. A intenção é, portanto, inventariar possíveis cruzamentos, como por exemplo: se aquele é o mago das iluminações profanas por sua apaixonada aposta na redenção nostálgica que inspira uma utopia, questionadora do presente a partir das lutas pretéritas com vistas para a emergência da Revolução; esta é o espaço dedicado à operacionalização teórico- prática da própria práxis revolucionária, uma vez que salvaguarda e atualiza o verbo de luta da classe trabalhadora, honrando os compromissos ancestrais dos que tombaram nas "rodas das carruagens majestosas do progresso". O sonho de Benjamim é com o futuro, assim como o da ENFF também o é, com o futuro de uma esperança. Ambos reconhecem a importância fundamental das batalhas pela memória inscrita na tradição dos oprimidos. Tanto a ENFF quanto o pensador são espiritualistas, isto é, concebem que mediante a hostilidade da luta de classes, os oprimidos não devem prescindir do auxílio das forças espirituais, àquela operacionaliza sua alma através da mística, esse a exerce por meio de sua fé nas forças messiânicas e redentoras da humanidade, produtoras de coragem, esperança, tenacidade e amor para a luta no presente.

Palavra-chave walter benjamim; ENFF; esperança. 


\begin{abstract}
The main objective of the current article is to weave together the revolutionary-romantic thought of the philosopher Walter Benjamim with the experience of the National School Florestan Fernandes (ENFF) of the MST. How would this Jewish-German thinker who lived through the tensions arising from the first half of the 20th century have a relationship with this rebellious school that emerged in the early 21st century? Is there a possibility of neural and coronary connections between both? What would be the theoretical and practical enrichment of this approach? It is not a matter of making the Benjamin theory fit the forceps in the ENFF experience, but rather a little history of points of intercession between their dreams and fears, respecting the time lapse that separates them and the singularities of each historical context. It is a battle-ball between embracing worldviews, ideas and ideals convergent that illuminate points of the historical intelligibility of our dramas and current expectations. The intention is, therefore, to inventory possible intersections, such as: if that is the magician of profane illuminations for his passionate bet on nostalgic redemption that inspires a utopia, questioning the present from the past struggles with a view to the emergence of the Revolution; this is the space dedicated to the theoretical-practical operationalization of revolutionary praxis itself, since it saves and updates the working class struggle verb, honoring the ancestral commitments of those who fell on the "wheels of the majestic chariots of progress". Benjamin's dream is about the future, just as ENFF's is, witch the future of hope. Both recognize the fundamental importance of the battles for the memory inscribed in the tradition of the oppressed Both the ENFF and the thinker are spiritualists, that is, they conceive that, through the hostility of the class struggle, the oppressed they should not do without the help of the spiritual forces, the one that operationalizes their soul through the mystical ,he exercises this through his faith in the messianic and redemptive forces of humanity, producing of courage, hope, tenacity and love for the present struggle.
\end{abstract}

Key-word walter benjamim; ENFF; hope.

\title{
Introdução
}

A nossa condição de professor favelado e amante da história e da poesia jamais poderiam ser olvidadas dentro da corrente narrativa, pois a favela e a floresta que habitam em mim exigem o grito contra o conjunto de expropriações que mastigam lestas e indiferentes a carne da vida dos pobres. Este artigo é uma denúncia aberta à destrutividade da reprodução sociometabólica do modo -de- produção capitalista a partir da crítica romântica de Walter Benjamim ${ }^{1}$ ao projeto de modernidade, bem como à luz da resistência campesina do MST através de sua Escola Nacional. Pois, se essa é o anúncio de um novo sol que raia no céu da história, o patrimônio mais bem-sucedido do MST para romper a "cerca da ignorância"; aquele é o pensador que deposita toda sua fé e entusiasmo na redenção dos "de baixo"2, isto é, a favor do Messias profano, a classe trabalhadora e, teológica e

\footnotetext{
1 A visão de mundo romântica aqui adotada tem a seguinte conotação filosófico-existencial, qual seja: conceboa inspirado na notável reflexão de Michael Lowy, isto é, como "um protesto cultural contra o desencantamento capitalista do mundo, contra a civilização burguesa moderna em nome de valores pré-capitalistas. De certo modo, o romantismo pode ser considerado como uma tentativa, animada pela energia do desespero e iluminada pelo sol negro da melancolia (Gerard de Nerval), de re-encantamento do mundo sob formas religiosas, nos românticos tradicionalistas ou profanos". LOWY, Michael. Walter Benjamin e o Surrealismo. As núpcias químicas de dois materialismos. Limiar, vol. 3, no. 6, 2016.

2 A mim me parece que quem mais proficuamente utilizou a referida expressão foi Emir Sader, referindo-se aos sujeitos sociais despojados do seu direito de ser, de ser mais. Tal marginalização decorre da inscrição do proletariado no seio do processo produtivo, seja como mercadoria, através da qual o patrão irá lucrar à custa de seu sangue e suor, seja através da composição do "exército industrial de reserva", instrumental medonho para a árida exploração do trabalho, e conseqüentemente, valorização do valor De maneira que várias nomenclaturas foram dadas aos espoliados no transcurso da história, a saber: no século XVII, era a plebe; no XVIII, arraia-miúda;
} 
dialeticamente, contra a barbárie do próprio Anticristo, as assassinas classes dominantes. Estando aberto à dialética da denúncia e do anúncio reitero a frase de Paulo Freire:

\begin{abstract}
"não há utopia verdadeira fora da tensão entre a denúncia de um presente tornandose cada vez mais intolerável e o anúncio de um futuro a ser criado, construído, política, estética e eticamente por nós, homens e mulheres". (ENFF. Agenda 2015: 10 anos ENFF (2005-2015).
\end{abstract}

Mesmo separados por quase um século, Benjamim e a ENFF são críticos ardorosos do decantado progresso e signatários das memórias revolucionárias e/ou redentoras dos oprimidos. De maneira que, tanto um quanto outro não acreditam que a Revolução seja fruto "natural" do desenvolvimento das forças produtivas à maneira do marxismo evolucionista vulgar, mas sim como "(...) a interrupção de uma evolução histórica que conduz à catástrofe" (LOWY, 2002, p.201). A revolução seria, portanto, nem tanto o motor da história, mas sim o freio de emergência deste trem catastrófico, no qual somos tripulantes à beira da morte, passageiros deste trem incestuoso que mata sua própria Mãe Natureza, impiedoso mutilador da sagrada Pacha Mama dos ameríndios.

De acordo com o historiador Michel Lowy, o marxismo é um canteiro de obras, sobre o qual continua a trabalhar as gerações de marxistas críticos. (LOWY, 1997). Epistemologicamente, Benjamim renova o marxismo, concebendo-o não como um receituário à maneira dos marxistas vulgares, mas sim como uma fonte para pensar/agir mediante o perigo. È precisamente pela atual catástrofe, geradora da destruição planetária que convoco suas iluminações para o diálogo.

0 desejo de entrelaçar a ENFF e o filósofo decorreram precisamente de nossa militância engajada, isto é, esta escolha é fruto de nossa experiência na luta, seja nas manifestações de rua, rebelando-nos contra as transgressões éticas de que somos vítimas cada vez mais sofridas, seja com o MST em escolas, marchas, barricadas, ocupações e assentamentos, corpo a corpo e de mãos dadas como no tempo dos empates ${ }^{3}$, erguendo paralelepípedos como fortalezas para o alto ${ }^{4}$, e não escrevendo sobre eles com ares superiores de diletantismo. De modo que foi dentro da ENFF, no momento mesmo de encantamento com toda a sua potência revolucionária que re-lembrei dos escritos

no século XIX com a epopéia da conquista burguesa sobre o globo terrestre, os não- normatizados recebiam um sem-número de pechas: mendigos, loucos, neurastênicos, doentes, mendicantes, vadios, bêbados, leprosos e/ou vagabundos. No século XX, os favelados, os pés-rapados. Hoje, no século XXI, continua o massacre das populações negras e faveladas, índios, camponeses sem terra e o poviléu sem eira nem beira. Esse verdadeiro Holocausto Brasileiro que perdura até hoje está inscrita em nossa formação histórica de cunho racista, belicista, misógina, discriminatória, patriarcal e elitista. A despeito da vitória dos dominadores, tal morticínio dos oprimidos pelas classes dirigentes, todavia, não ocorre sem resistência daqueles. Ao contrário, eles resistem a esse processo histórico através de atos, gestos, palavras, manifestações, piquetes, paralisações, ocupações de prédios públicos, marchas, greves, passeatas, simulações, eufemismos e, muitas vezes, esses insubordinados sujeitos históricos pagam com a própria vida pela boniteza de lutar e a coragem de amar, haja vista que desde o fim do período da ditadura empresarial-militar até hoje mais de 1.600 lideranças camponesas foram mortas conforme dados da CPT (Comissão Pastoral da Terra).

3 Empate era a rebelde tática adotada pelos povos da floresta contra a violência dos capitalistas da terra e seus defensores armados (jagunços). Wilson Pinheiro, Chico Mendes e diversos povos ribeirinhos utilizaram largamente essa estratégia para refrear os ímpetos de destruição da floresta. Sumariamente, consistia em pessoas que iam para o meio da mata, totalmente desarmados e de todos de mãos dadas (geralmente trinta a cinqüenta a pessoas iam, desde crianças até idosos), a fim de impedir a morte de árvores e outros seres vivos, protegendo a vida, o lindo cinturão verde da selva. Muita vez, tal resistência logrou êxito, e relativo recuo dos grileiros assassinos.

4 “(...) No 'Discurso a Paris', que deveria concluir As flores do mal, Baudelaire recorda a magia das mãos que erguem paralelepípedos como fortalezas para o alto. E o grande sonho terrorista que Marx encontra entre os conspiradores é apontado por Benjamin como tendo a sua contrapartida em Baudelaire. A ira, o rancor, o sangue frio, a irreverência, a paixão que animaram meio século de lutas de barricadas em Paris estão presentes no espírito de Baudelaire". D’ANGELO. Marta. A modernidade pelo olhar de Walter Benjamin. ESTUDOS AVANÇADOS 20 (56), 2006.p. 241 
benjaminianos, uma vez que- conforme assevera a tese VI sobre o conceito de história- cabe ao historiador o dom de despertar no passado as centelhas da esperança, pois nem os mortos estarão em segurança se o inimigo continuar a vencer.

Há muito mais convergências entre Benjamim e a ENFF do que pode imaginar nossa vã filosofia. São convergências de idéias-ações estrelares ${ }^{5}$ : os sonhos e esperanças de ambos contra a fúria implacável dos poderosos são pontos confluentes das suas respectivas críticas à corrosão da experiência e da vida sob a égide do fascismo. Há neles uma justa raiva contra a atual catástrofe em curso ocasionado pelo rolo compressor da destrutiva barbárie capitalista. Suas respectivas experiências revelam profunda indignação e afetividade socialista contra os dominadores que espezinham os corpos dos que estão prostrados no chão, na crítica radical ao cortejo triunfal dos vencedores. ${ }^{6}$

Walter Benjamim legou para o seio da tradição marxista o estudo sobre a dimensão onírica situada nas interrupções da vigília e do sonho, aquela que privilegia a força espiritual e redentora dos oprimidos no transcurso da história. Este autor deposita fé na memória dos que tombaram, colocando neles a esperança da redenção necessária. Através de suas iluminações profanas aprendemos que é preciso ir além do decrescimento das expectativas, encontrando nos desesperançados a força da esperança presente. A ENFF, correlatamente, é fruto da épica luta dos esfarrapados do mundo, assumindo a imperiosa necessidade de enfrentar as contradições sociais do capital por meio do engajamento, entendido aqui como a ampla, plural e intransigente participação política dos subalternos em sua batalha por uma vida digna.

Ao escovar a história a contrapelo à moda de Benjamim, a ENFF anda na contramão da perspectiva societária que corrobora com os processos de subjugação burguesa. Ao contrário, na medida em que visa suplantar a sociedade sob o domínio das classes dirigentes contribui para o progressivo rompimento das restrições ontológicas inerentes à sua reprodução sociometabólica. Sua potência revolucionária reside em construir com os sujeitos subjugados a edificação de uma visão de mundo que acelera a chegada de uma ordem social baseado na igualdade substantiva.

Tal dimensão está consoante com as preocupações sociais do MST, no sentido de construção de uma cultura dissidente, capaz tanto de organizar o pessimismo quanto de alicerçar o otimismo em bases revolucionárias. Pessimismo este que, na acepção de Benjamim é ativo, já que "(...) esta aqui a serviço da emancipação das classes oprimidas. Sua preocupação não é com o 'declínio' das elites ou da nação, mas sim com as ameaças que o progresso técnico e econômico promovido pelo capitalismo faz pesar sobre a humanidade". (LOWY, 2005).

A aproximação mais certeira que podemos tecer entre o pensador judeu-alemão e a ENFF é de ordem ontológica ${ }^{7}$, pois há nesta e naquele um profundo comprometimento moral com a reflexão-ação a respeito do sentido do ser social, no sentido de examinar as adversas condições reais da realidade, elaborando efetiva e afetivamente a centelha da esperança para que bem unidos façamos a luta pela real transformação societária. Certamente uma postura bela, radical e teológica. Bela porque é bem-proporcionada à utopia, ao desejo de justiça, ao amor à solidariedade. Radical porque agarra as questões

\footnotetext{
5 As ideias se relacionam com as coisas como as constelações com as estrelas" (BENJAMIN, Origem do drama trágico alemão, [Prólogo epistemológico-crítico], p. 22).

6 "Todos os que até hoje venceram participam do cortejo triunfal em que os dominadores de hoje espezinham os corpos dos que estão prostrados no chão". (BENJAMIN, Magia e técnica, arte e política, [Tese VI- Sobre o conceito de história], p. 225).

7 Ontologicamente, para ambos a história deve ser escovada a contrapelo, isto é, concebendo-a do ponto de vista da história das gerações vencidas, em franca oposição à história oficial do 'progresso', cuja identificação com as classes dominantes, oculta o potencial utópico inscrito nas lutas dos oprimidos. Utilizo-os, pois eles estão ao lado dos condenados da terra, dos que caíram sob as rodas das carruagens majestosas e magníficas denominadas "Civilização, Progresso e tesouros culturais”. (LOWY, 2010).
} 
sociais pela raiz à moda de Karl Marx 8 , gerando contrapontos ideológicos essenciais para a luta de classes, e que ao fazê-lo gera entusiasmo pela luta política e paixão à sabedoria ancestral inscrita na tradição dos oprimidos, bem como causa ódio da classe burguesa endinheirada sintonizada com os valores egoístas e mesquinhos de acumulação cega de capital, geradora da atual catástrofe da Terra. Teológica, pois para Benjamim "cada segundo era a porta estreita pela qual podia penetrar o Messias", a Revolução; enquanto o MST surgiu sob o amparo da Comissão Pastoral da Terra (CPT), instituição surgida em 1975, vinculada a uma ala mais progressista da Igreja Católica pós- Concílio Vaticano II9 , no qual emergiam com forças totais as Comunidades Eclesiais de Base arregimentando fiéis para lutar pelo paraíso no céu e também na própria vida terrena. Convém frisar que Teologia e Revolução não são antagônicas, uma vez que as lutas populares da América Latina nos últimos trinta anos, sobretudo, a partir da Teologia da Libertação- com opção preferencial pelos pobresdemonstra uma bem-sucedida aliança política e espiritual entre cristãos e movimentos revolucionários que lutavam pelo "paraíso" também na Terra, haja vista o MST, o zapatistismo, a revolução nicaguarense.

\title{
Bate - bola entre BENJAMIM e a ENFF do MST
}

\begin{abstract}
"A luta de classes, que um historiador educado por Marx jamais perde de vista, é uma luta pelas coisas brutas e materiais, sem as quais não existem as refinadas e espirituais. Mas na luta de classes essas coisas espirituais não podem ser representadas como despojos atribuídos ao vencedor. Elas se manifestam nessa luta sob a forma da confiança, da coragem, do humor, da astúcia, da firmeza, e agem de longe, do fundo dos tempos. Elas questionarão sempre cada vitória dos dominadores. Assim como as flores dirigem sua corola para o sol, o passado, graças a um misterioso heliotropismo, tenta dirigir-se para o sol que se levanta no céu da história. 0 materialismo histórico deve ficar atento a essa transformação, a mais imperceptível de todas." ( Walter Benjamim).
\end{abstract}

Vejo a Escola Nacional Florestan Fernandes como uma flor - formosa e rebelde- que irrompeu no asfalto cimentado pela tortuosa estrada da era "pós- ideológica" do presumido "fim da história"10. Essa formosa flor - a rosa do povo drummondiana11- é a Escola Nacional

8 A concepção marxiana acerca da radicalidade é: “(...) Ser radical é agarrar a coisa pela raiz. Mas a raiz, para o homem, é o próprio homem". Crítica da filosofia do Direito de Hegel- [2.ed revista]. - São Paulo : Boitempo, 2010. P.151.

9 Segundo ( FERNANDES; STÉDILE, 2005 , P.20 Apud COELHO , 2010, p. 78), a CPT foi a aplicação da Teologia da Libertação na prática, o que trouxe uma contribuição importante para os camponeses pelo prisma ideológico. Os padres, agentes pastorais, religiosos e pastores discutiam com os camponeses a necessidade de eles se organizarem. A Igreja parou de fazer um trabalho messiânico e de dizer para o camponês: 'Espera que tu terás terra no céu'. Pelo contrário, passou a dizer: 'Tu precisas te organizar para lutar e resolver os teus problemas aqui na Terra'. A CPT fez um trabalho muito importante de conscientização dos camponeses. Sobre isso ver: FERNANDES, Bernardo M.; STEDILE, João P. Brava Gente: a trajetória do MST e a luta pela terra no Brasil. 3a Ed. São Paulo: Editora Fundação Perseu Abramo, 2005. p. 20

10 Este termo emergiu no seio debate historiográfico no contexto do colapso da URSS e a queda do muro de Berlim. Para os ideólogos do capital, chegamos ao fim da era ideológica, já que o socialismo soçobrou e o capitalismo triunfou soberano no mundo. Um dos seus mais ardorosos defensores foi Fukuyama. 0 que nos parece evidente é que a tentativa de negar a existência de visão de mundo antagônica ao sistema capitalista é puramente ideológica, uma vez que esta assume os valores de reprodução sociometabólica do capital, demonstrando assim seu total alinhamento com as prerrogativas de acumulação capitalista. Ao arrepio desta noção redutora, problematizo as correntes de ação e pensamento contra-hegemônicas à maneira de Walter Benjamim e da ENFF do MST.

11 A expressão realiza menção ao livro do maravilhoso poeta de Itabira. A rosa do povo foi escrito sob os auspícios da dramática II Grande Guerra Mundial. Grávido de crítica e sensibilidade, o livro propõe o questionamento não apenas sobre o ser e estar do poeta perante o mundo e sua posição em face dos problemas políticos e sociais do seu tempo, mas também traz o sentimento moral de elevar a reflexão sobre os homens com os primores do lirismo existencial. 0 prefácio da $21^{\circ}$ edição publicada no ano de 2000 traz o seguinte libelo: "A rosa do povo despetala-se, ou ainda conserva o pudor da alva? E um anúncio, um chamado, uma 
Florestan Fernandes do MST. Em seu desabrochar, um segredo comunica-se. Esta charada sincopada é precisamente o processo de união da classe trabalhadora universal no enfretamento hostil da realidade nua e crua. Esta é a fina flor antifascista, onde a máxima de Karl Marx é praticada e entoada em várias vozes: "trabalhadores do mundo inteiro, univos!".

Por um curioso heliotropismo, essa flor dirige sua corola para o novo sol que se levanta no céu da história. Esse novo sol da esperança de um futuro é herdeiro da experiência história de autotransformação e autoformação dos trabalhadores. A ENFF à semelhança de Walter Benjamim compreendeu no seio de sua atividade crítico-prática o importante alerta de Marx contido no preâmbulo do Estatuto da Associação dos Trabalhadores datado de 1864, na qual "a emancipação dos trabalhadores deve ser obra dos próprios trabalhadores", isto é, na ENFF é a própria classe trabalhadora que constrói através de sua práxis revolucionária, ao mesmo tempo, a transformação de si mesmo e das circunstâncias históricas adversas que a cercam.

A consciência de classe experimentada na ENFF ajuda a fomentar o espírito de radicalidade emancipadora da classe trabalhadora, sem dúvida, dimensão indispensável para ensejar e efetivar mudanças substantivas. A ENFF compreende mediante práxis revolucionária que a "essência humana" que visam construir não pode ser definida abstratamente, mas sim a partir do conjunto das relações sociais mediatizada pelos trabalhadores, por sua vez, baseado no "amor, trabalho, linguagem, a realidade transindividual da humanidade". (LOWY, 2012, p.24).

Numa passagem luminosa, Balibar mostra a reciprocidade dialética entre a ontologia transindividual e o conceito de práxis revolucionária: 'ousemos dizer: as relações sociais aqui designadas nada mais são do que uma incessante transformação, uma revolução permanente. (BALIBAR, apud LOWY, 2012. p.24)

Os trabalhadores associam-se a redenção da humanidade precisamente pelos sofrimentos universais que suportam dentro da jaula de aço. Assim como Benjamim, a ENFF do MST de modo algum olvida a luta e as causas perdidas da classe trabalhadora, ou seja, a interpretação da história é realizada a partir do ponto de vista dos vencidos. Eis o trunfo mor da Escola do MST: alertar para a consciência necessária da humanidade ameaçada.

\begin{abstract}
não é difícil perceber as graves implicações de um fracasso de uma tentativa de impugnar as tendências destrutivas de desenvolvimento, que impõe seu poder não apenas no domínio militar, mas também na produção econômica em relação da humanidade com a natureza. Assim, o fardo de que estamos falando indica tanto as graves dificuldades emergentes do desafio histórico claramente identificável, sublinhando pela inegável urgência do tempo histórico para empreender a ação corretiva necessária, quanto à responsabilidade que cada indivíduo para que alcancemos êxito. (MÉSZÁROS, 2007)
\end{abstract}

De modo semelhante, as teses sobre o conceito de história de Walter Benjamim também evidenciam essa radicalidade, sobretudo, pela evocação messiânica e revolucionária subjacentes, seja em suas alegorias, idiossincrasias, epifanias, pensamentos insubmissos, seja na marca poética e pictórica que definem este libelo como "(...) um dos documentos mais importantes do pensamento revolucionário desde as Teses sobre Feuerbach, de 1845' (LOWY, 2002,p.203). Salta aos olhos na leitura da supracitada Tese IV,

esperança embora frágil, pranto infantil no berço? Talvez apenas um ai de seresta, quem sabe. Mas há um ouvido mais fino que escuta, um peito de artista que incha, e uma rosa se abre, um segredo comunica-se, o poeta anunciou”. ANDRADE, Carlos Drummond de. A Rosa do Povo. 21'edição. Rio de Janeiro: Record, 2000. 
a opção preferencial de Benjamim pela luta de classes, pois o essencial em sua exegese é precisamente "(...) a luta até a morte entre opressores e oprimidos, exploradores e explorados, dominantes e dominados"(LOWY, 2005, p.59). Para o enfretamento no contexto da interrupção da contínua vitória dos poderosos e seu cortejo triunfal, faz-se necessário alumiar as forças revolucionárias do passado para animar o presente, de modo que "(...)os antigos combates se voltam 'para o sol que esta a se levantar' mas, uma vez tocados por essa claridade, alimentam a consciência de classe daqueles que sublevam hoje" (LOWY,2005,p.61).

A reflexão benjaminiana contida nas Teses é uma crítica moderna e romântica ao projeto da modernidade, na medida em que

ela constitui uma forma heterodoxa do relato da emancipação: inspirando-se em fontes messiânicas e marxistas, ela utiliza a nostalgia do passado como método revolucionário de crítica do presente. Seu pensamento não e, então, nem "moderno" (no sentido habermasiano) nem "pós-moderno" (no sentido de Lyotard), mas consiste, sobretudo em uma crítica moderna à modernidade (capitalista/industrial), inspirada em referências culturais e históricas pré-capitalistas. (LOWY, 2005)

Benjamim, portanto, retira inspiração de fontes históricas românticas e précapitalistas, não no sentido de um mero retorno para o passado, mas da redenção nostálgica que inspira uma utopia revolucionária à medida que questiona abertamente o presente a partir das lutas pretéritas com vistas para a emergência da Revolução, ou seja, é o passado que alumia o presente. Não é demasiado recordar que Benjamim escreveu este libelo em discussão sob os auspícios da Segunda Guerra Mundial no contexto do pacto germanosoviético, bem como sob a perseguição da invasão nazista na Europa ${ }^{12}$.

Conforme lampeja a tese VI, a luta pelas condições materiais da existência jamais devem prescindir do auxílio das forças espirituais, pois não fosse o encorajamento moral advindas de uma dimensão de fé, as classes dominadas sucumbiriam no primeiro embate,

12 Como judeu fugiu da Alemanha do III Reich em 1933, ano que Hitler assume o poder da República de Weimar. Vai para a França, mas a soberana III República Francesa pós-decretação de guerra contra os nazistas, manda prender todos alemães em solo francês sob o álibi de serem cidadãos do país inimigo. Benjamim é capturado, internado e preso. Depois de passar por incontáveis dificuldades que assusta a imaginação sádica, Benjamim consegue sair da prisão para viver sob o faro de dobermann da Gestapo e das tropas de Vichy, liderada pelo franco- fascista colaborador dos nazistas, o Phellipe Pétain, o bastardo nada glorioso. Começa a virulenta caça as bruxas (judias,comunistas), aos bruxos( judeus, antifascista). Benjamim usa seus poderes místicos para lutar heroicamente contra o cortejo triunfal dos vencedores que o ameaça. Esconderijos. Fugiu com o mesmo ardor da policia como das ilusões progressistas. 0 cerco está se fechando. A Gestapo e a polícia do Estado Francês está em seu encalço. A perseguição prossegue com seu faro de pastor-alemão e drogados soldados viciados em torturar e matar. 0 que fazer mediante esse tormento? Benjamim resiste e continua a se esconder e fugir. Como Benjamim está no sul da França, o caminho menos arriscado para a fuga era pelos Altos Pirineus a fim de chegar à Espanha. Sobe as montanhas rochosas e alcança a terra de Cervantes, García Lorca, Dalí, mas também de Franco, o ditador de Guernica. È capturado pelas tropas franquistas. Sabendo que ia ser entregue as tropas coloboracionistas de Vichy opta pela injeção letal de morfina, deu-se em holocausto para que apredessemos a lutar - de todas as formas- contra o fascismo. Segundo o historiador Pedro Paulo Funari trata-se de um contexto histórico conturbado quando soava "meia-noite do século", no dizer de Victor Serge: “(...)deve-se recordar que este primeiro semestre de 1940 se mostrou profundamente depressivo para toda a intelectualidade ocidental, pois os avanços nazista e stalinista estavam caminhando sem freios. Isto explica o fato de o texto ter-se mantido inédito até o pós-guerra e, talvez de forma ainda mais clara, articular-se em tomo do horror (Grauen), não um terror ou medo abstrato, mas um tomar-se cinza, pálido, desfalecido: tomar-se grau, ou cinza, diante de um presente também cinza. 0 estilo do texto, fortemente estético, entremeado de citações poéticas e pictóricas, constrói-se, também, com essa imagética, como, em particular, nas analogias e metáforas: heliotropismo (IV) [5], um quadro que passa como um relâmpago (V), Angelus novus e a tempestade (IX), o salto do tigre na arena (XIV), o fruto nutritivo (XVII). Talvez o exemplo mais claro da construção poética esteja ao final da tese de número XII: "Denn beide niihren sich an dem Bild der geknechteten Vorfahren, nicht am Ideal der befreite Enkel" ("Porque um e outro se alimentam da imagem dos antepassados escravizados, e não dos descendentes liberados"). FUNARI, Pedro Paulo A. CONSIDERAÇÕES EM TORNO DAS "TESES SOBRE FILOSOFIA DA HISTÓRIA", DE WALTER BENJAMIN. CRÍTICA MARXISTA .p.47 .Disponível em“

https://www.ifch.unicamp.br/criticamarxista/arquivos_biblioteca/3_PPFunari.pdf. Acesso em: 30.09.2020. 
de maneira que o passado é iluminado pela força anímica dos combates atuais, e este, dialeticamente, é alimentado pelas lutas do pretérito.

\begin{abstract}
No entanto, cada novo combate dos oprimidos coloca em questão não só a dominação presente, mas também as vitorias do passado. As coisas finas e espirituais da luta atual "retroagem" ao passado longínquo - "fundo longínquo do tempo". 0 passado é iluminado pela luz dos combates de hoje, pelo sol que se levanta no céu da história, A metáfora do sol era uma imagem tradicional do movimento operário alemão: "Broder, zuSonne, zur Freiheit"(Irmãos,rumo ao sol,rumo à liberdade), proclamava o velho hino do partido socialdemocrata, Mas tratava-se do sol do futuro que ilumina o presente. Aqui, graças ao sol do presente, o significado do passado se transforma para nós. Assim como, no exemplo citado acima, Thomas Munzer e a guerra dos camponeses no século XVI foram reinterpretados por Friedrich Engels - e, mais tarde, por Ernst Bloch - a luz dos combates do movimento operário moderno. (LOWY, 2005, p.60)
\end{abstract}

Bebendo em fontes poético-românticas, Walter Benjamim realiza a evocação das lutas do tempo pretérito para encorajar a luta por uma sociedade comunista no contexto da aurora do novo sol da história. As dimensões finas e espirituais das lutas de hoje retrocedem ao passado longínquo. À revelia de uma epistême limitadora que pretende conservar a realidade tal qual ela é, Benjamim jamais esquece uma dimensão inalienável do materialismo histórico-dialético de Marx, a saber: o da sociedade cindida em classes, aliada a necessidade de transformá-la radicalmente com o auxílio da força messiânica e redentora dos vencidos.

A ENFF, por seu turno, não difere em nada deste propósito, uma vez que intenta em seu fazer-se ${ }^{13}$ disponibilizar ao conjunto dos militantes e dirigentes um valoroso processo de formação ética e política sob o ponto de vista dos vencidos a fim de manter acesa e flamejante a chama da consciência revolucionária com vistas à compreensão/ transformação do mundo real. Sem uma leitura crítica das lutas do passado não há futuro plausível de redenção. Paralelamente, a poética benjaminiana, "conduz a uma preocupação essencial com os excluídos e com os párias da sociedade capitalista" (EAGLETON apud SANTOS NETO, 2007). Ora, esse é justamente o papel fundamental da ENFF: seu compromisso de intercambiar práticas, idéias e processos anti- sistêmicos dos movimentos sociais do mundo inteiro, oferecendo relevantes contrapontos ideológicos e ontológicos sob o ponto de vista dos vencidos para a destruição planetária operacionalizada pelos assassinos burgueses em sua terrível casa do desespero, o capitalismo.

Assim, à luz da VI tese benjaminiana, o teórico-prático deve "arrancar a tradição ao conformismo, que quer apoderar-se dela. (...) pois (grifo nosso) também os mortos não estarão em segurança se o inimigo vencer.". De modo que tanto a memória histórica da coragem bravia dos revolucionários que sacudiram o mundo, colocando-o de cabeça pra baixo, quanto o dom de despertar no passado as centelhas da esperança é recurso utópico e revolucionário contido na beleza alegórica de sua filosofia da práxis ${ }^{14}$. Ambos têm este

13 A noção de fazer-se aqui empregada é tributária da clássica obra, " A formação da classe operária inglesa", do notável historiador E.P. Thompson. Para o marxista britânico, o fazer-se é "(...) um processo ativo. Que se deve tanto à ação humana, como aos condicionamentos." Ou seja, o fazer-se é apreendido historicamente por meio da experiência concreta dos sujeitos no movimento da história. Sobre isso ver: THOMPSON, Edward P. A formação da classe operária inglesa. A árvore da liberdade- Vol.1. Rio de Janeiro: Paz e Terra, 1987. Prefácio.

14 Como nos é sabido, o termo "filosofia da práxis" foi consagrado pelo dirigente comunista Antonio Gramsci para re-nomear a perseguição ferrenha do fascismo italiano ao materialismo histórico-dialético de Marx e Engels. A expressão foi cunhada em seu longínquo período de reclusão na prisão, na qual escreveu os célebres "Cadernos do Cárcere", com o duplo desejo: de um lado, driblar a censura da "cadela do fascismo que está sempre no cio"( como nos adverte Brecht), mas também com a intenção de aparelhar ideologicamente a classe trabalhadora na construção de sua atividade revolucionária crítico-prática contra a acachapante e repressora ideologia dominante. Práxis é, à luz de Antonio Gramsci, antes de tudo, a ação livre da autotransformação humana no transcurso mesmo de atividade teórico-prática. 
objetivo fundamental: fomentar a explosão do continuum da história própria das classes revolucionárias no momento da ação.

Assim, Benjamin tornar-se o mago ${ }^{15}$ que invoca o anjo da história. É no meio ambiente das epifanias redentoras da humanidade que Benjamin invoca o anjo da história ${ }^{16}$, Angelus Novus. Seus elementos são os destroços advindos pelo progresso ininterrupto, os cacos da temporalidade fria, vazia e homogênea deste tempo saturado de "agoras". Elas estão inscritas sob a forma de estilhaços das gerações derrotadas. É preciso, portanto, ouvir os silêncios na história, proveniente dos destroços e memórias disruptivas dos oprimidos. "É preciso lutar para impedir que a classe dominante apague as chamas da cultura passada, e para que elas sejam subtraídas do conformismo que as ameaça (Tese VI)" (LOWY, 2010). Assim, preservando o potencial utópico dos oprimidos, ao mesmo tempo, criticando a destruição da cultura oficial, os excluídos da história poderão apropriar-se com mais vigor da dimensão revolucionária que recobre espiritualmente sua experiência prenha de fé e coragem. Pois, somente o "Messias poderá fazer o que o Anjo da Historia é impotente para realizar: deter a tempestade, cuidar dos feridos, ressuscitar as mortos e rejuntar a que foi quebrada".(LOWY, 2005,p.94).

No que diz respeito à Tese VI de Benjamim, podemos oportunamente traçar mais um cruzamento profícuo entre esta e a ENFF, posto que dentro da práxis educativa da Escola haja todo um esforço quotidiano de uma luta política pela memória, pois se a classe dominante procura apagar os vestígios de resistência da cultura passada, tornando-as inócuas ou em conformidade com o status quo, lá existe um processo histórico através do qual a memória e a história de luta da classe trabalhadora são evocadas, incorporadas e rememoradas na dinâmica da luta-vida. Sendo a memória um recurso do presente, a ENFF levanta o caráter político da mesma, trazendo à luz tanto os que tombaram na marcha genocida do progresso, quanto recordando os que dedicaram a sua vida a causa da emancipação humana, as lutadoras e os lutadores do povo ${ }^{17}$.

Nesse sentido, a história é um acúmulo não de progresso, como pretende a filosofia da história positivista do século XIX, mas de catástrofes, o "amontoado de ruínas que cresce até o céu"(Tese IX). Cabe, portanto, a cada geração explodir o continuum da história. Parar o tempo, à maneira daqueles que se colocam contra a ordem uniformizadora do progresso, como por exemplo: os trabalhadores seringueiros, camponeses e as populações indígenas em cruciais e impressionantes momentos de nossa história recente, quando pararam a marcha do "progresso", do mercado e da "modernização" (ALBURQUERQUE, 2015). Basta lembrar as perseguições e mortes de homens e mulheres que ousaram desafiar a lógica expansiva do capital, como ocorreu no fatídico crepúsculo do dia 22 de dezembro do ano de 1988, com o lutador socialista, o corajoso amante do cinturão verde da floresta e da reforma

15 Não é um bruxo, porque não se coloca como um guerreiro da luz ou profeta do Novo Aeón, ao contrário, ele experimentou a queda e aprendeu a respeitar os limites da magia - não podemos esquecer que o feiticeiro lida com a vontade, enquanto o mago lida com a mágica espiritualidade da linguagem visual e escrita. Há magia na linguagem: “(...) toda língua se comunica em si mesma; ela é, no sentido mais puro, o meio [Medium] da comunicação. A característica própria do meio, isto é, a imediatidade de toda comunicação espiritual, é o problema fundamental da teoria da linguagem, e, se quisermos chamar de mágica essa imediatidade, então o problema originário da linguagem será a sua magia" (BENJAMIN, Escritos sobre mito e linguagem, [Sobre a linguagem em geral e sobre a linguagem do homem], p. 54).

16 "Há um quadro de Klee que se chama Angelus Novus. Representa um anjo que parece querer afastar-se de algo que ele encara fixamente. Seus olhos estão escancarados, sua boca dilatada, suas asas abertas. 0 anjo da história deve ter esse aspecto. Seu rosto está dirigido para o passado. Onde nós vemos uma cadeia de acontecimentos, ele vê uma catástrofe única, que acumula incansavelmente ruína sobre ruína e as dispersa a nossos pés. Ele gostaria de deter-se para acordar os mortos e juntar os fragmentos. Mas uma tempestade sopra do paraíso e prende-se em suas asas com tanta força que ele não pode mais fechá-las. Essa tempestade o impele irresistivelmente para o futuro, ao qual ele vira as costas, enquanto o amontoado de ruínas cresce até o céu. Essa tempestade é o que chamamos progresso"(BENJAMIN,Magia e técnica, arte e política, [Tese IX Sobre o conceito de história], p.226).

17 É como esse afável epíteto que o MST classifica os corajosos sujeitos que contribuíram diretamente para a causa da efetiva emancipação humana. São alguns deles: Florestan Fernandes, Paulo Freire, Antônio Candido, Josué de Castro, Rosa Luxemburgo, István Mészáros, Karl Marx, Carlos Marighela, Carlos Nelson Coutinho, Che Guevara, Maria Lacerda de Moura, Frida Khalo, entre tantos outros e tantas outras. 
agrária, o saudoso combatente Chico Mendes ${ }^{18}$. Este seringueiro acreano que lutando com e pelos os povos da floresta desafiou a tirânica lógica irrefreável do capital foi friamente assassinado pelos capitalistas da terra no quintal de sua própria residência em Xapuri, no Acre. Dessa maneira, o propalado e defendido progresso carrega inexoravelmente sua marca de morte e destruição. Toda resistência ao decantado progresso é inevitavelmente mortífero, haja vista o trágico morticínio em Eldorado dos Carajás ${ }^{19}$. Tornar-se dever revolucionário do teórico-crítico atentar para o verdadeiro horror da imensa corvéia dos despojos a que chamamos bens culturais. Ė precisamente por isso que Benjamim afirma na Tese VII sobre o conceito de história que nunca houve monumento da cultura que não fosse também monumento da barbárie, haja vista a inexorável destrutividade sob a qual o progresso finca suas raízes.

Nesta conformidade crítica à ideologia do progresso que Benjamin irá dizer, no clímax regressivo de 1940: "A tradição dos oprimidos nos ensina que o 'estado de exceção' em que vivemos é na verdade a regra geral" (BENJAMIM, 2012). Nada de novo sob o sol no front dos oprimidos: exploração, doença e morte. A história até aqui tem na excepcionalidade das formas de dominação a sua regra, a sua marca incontornável. A depredação ambiental dos capitalistas, a violência plurissecular contra índios, pobres e camponeses, a tricentenária subsunção do trabalho pelo capital nos faz lembrar que a regra geral é o permanente estado de guerra.

E esses destroços se tornam no pensamento uma das belas artes, como um mosaico: "As alegorias são, no reino dos pensamentos, o que as ruínas são no reino das coisas"20. Por essas e outras que o materialismo histórico não pode prescindir da dimensão teológica de caráter revolucionário. Para ele, a história não é concebida através de um eterno retorno,

18 Nascido no dia 15 de dezembro de 1944 recebeu o nome de seu pai: Francisco Alves Mendes Filho. Tornouse Chico como a maioria dos meninos de nome Francisco. Cresceu no seringal Porto Rico, em Xapuri, e com dez anos de idade já cortava seringa sozinho para ajudar na produção de seu pai. Logo quis aprender mais coisas e com a ajuda de um amigo que morava perto de sua casa, aprendeu a ler e escrever. Chico começou então a ajudar o seu povo, fazia reuniões, explicava a realidade das coisas e tentava organizar homens e mulheres da floresta para acabar com a exploração dos patrões. Foi ameaçado e perseguido por isso. Pela primeira vez, Chico soube o que era sentir medo. Mas sua coragem era ainda maior. Era preciso resistir contra o desmatamento e da transformação da floresta em pasto foi quando surgiu o primeiro Sindicato de Trabalhadores Rurais do Acre. Logo a idéia se espalhou. Outros sindicatos surgiram, a igreja se juntou à luta dos seringueiros e, nas cidades, muitos começaram a perceber que um drama se desenrolava nas matas acreanas. Chico Mendes foi preso e torturado, Wilson Pinheiro foi assassinado, Ivar Higino e outros seringueiros também tombaram sob a sanha dos pistoleiros. Os índios e os ribeirinhos se uniram aos seringueiros, dando origem a Aliança dos Povos da Floresta, e liderados por Chico Mendes fizeram ecoar no mundo que a floresta era a sua casa e sua causa, e isso ninguém podia lhes tirar. Mas seus inimigos eram muitos e poderosos. E assim, ao entardecer do dia 22 de dezembro de 1988, Chico foi baleado e morto na porta dos fundos de sua casa no município de Xapuri...e os povos da floresta choraram. Mataram Chico, o homem, mas não conseguiram matar seu espírito e sua luta. Os inimigos do Chico foram derrotados por sua morte. As idéias que Chico defendeu impregnaram os corações dos homens de bem deste mundo e sua voz se faz ainda mais forte. Hoje são muitos Chicos lutando e seu espírito guia os povos da floresta e nos lembra sempre que a floresta é a nossa casa, nossa vida e nossa mãe e assim será para sempre. Viva CHICO REI SERINGUEIRO! Biografia extraída no Museu Chico Mendes em Xapuri- AC visitado por mim em dezembro de 2018, coincidentemente, exatamente no mês que se completa 30 anos de sua desencarnação para o plano espiritual.

19 "Carajás, região localizada no sudeste do Pará. Recebeu essa designação em função da serra dos Carajás, onde antigamente viviam os povos indígenas do mesmo nome. 0 centro da região a cidade de Marabá. Foi no município de Paraupebas que ocorreu o massacre de 19 sem-terra, em 17 de abril de 1996, durante uma manifestação na rodovia local, praticado pela Polícia Militar e por fazendeiros. Atéhoje nenhum dos 156 policias e oficiais envolvidos no massacre sofreu qualquer punição ou julgamento. Em março de 1998, oito desses mesmos policiais envolveram-se no assassinato de mais dois líderes do MST na região" (Fernandes, Bernardo Mançano e Stedile, João Pedro. Brava gente: a trajetória do MST e a luta pela terra no Brasil. São Paulo: Editora Fundação Perseu Abramo, 1999, nota 13, p.144)

20 "A fisionomia alegórica da história natural, que o drama trágico [barroco] coloca em cena, está realmente presente sob a forma da ruína. Com ela, a história transferiu-se de forma sensível para o palco. Assim configurada, a história não se revela como processo de uma vida eterna, mas antes como o progredir de um inevitável declínio. Com isso, a alegoria coloca-se declaradamente para lá da beleza. As alegorias são, no reino dos pensamentos, o que as ruínas são no reino das coisas". (BENJAMIN, Origem do drama trágico alemão, pp. 192-193). 
mas como um "progredir de um inevitável declínio". O presente do pesquisador é formado pela relação dialética entre o presente com algum momento perdido nas lutas pretéritas. 0 passado dirige um autêntico apelo à redenção. Ele é que pode nos redimir das catástrofes e das ruínas que se acumulam até o céu. Para o teórico-crítico importa, portanto, fazer uma ponte entre o aqui e o agora de perigo e o outrora- ocorrido ${ }^{21}$, re-memorando todos os pisados das gerações derrotadas.

Como a ENFF possibilita em sua experiência de classe, o pleno desabrochar das potencialidades redentoras da humanidade humilhada? Na Escola há a tentativa- romântica e revolucionária - de lembrar as gerações derrotadas, jamais denegando o assassinato em larga escala contra os despossuídos e, dentre eles, sobretudo, os camponeses pobres e radicais. Dentro da ENFF existe uma luta política da memória, no sentido de historicizar toda a ancestralidade de luta camponesa que graças a sua libertária coragem de lutar transformou radicalmente o "Breve século XX"22. Segundo o eminente historiador Eric Hobsbawm, este foi o mais revolucionário século da história da humanidade precisamente pelo poder rebelde e insubmisso do campesinato, haja vista as comunistas revoluções camponesas, tais como: a mexicana, cubana, russa, chinesa e vietnamita. Em sua práxis, oxalá, a ENFF não só lembra os mortos como também os incorpora em sua luta-vida quotidiana, fortalecendo os elos perdidos da consciência revolucionária de ontem e hoje, ajudando a re-atar os nós da classe trabalhadora. Assim, a Escola Nacional do MST ao relembrar e ressuscitar os mortos contribui sobremaneira para trazer a lume o caráter libertário do luto, a fim de alicerçar as bases e exigências de uma vida realmente digna aos vivos e aos finados. Nunca os mais de 1.600 camponeses mortos desde a 'abertura democrática' em 1985 serão esquecidos, mas sim incorporados na luta como ancestrais que carregam os inestimáveis e sublimes elementos de memória revolucionária: resistência, fé, coragem e amor. A propósito, viva a irmã Dorothy Stang. Viva!

\section{Ponto luminoso de inter-ligare umbilical: a mística}

È nítido como o sol a similitude da visão de mundo mágico-mística entre Walter Benjamim e a ENFF, enquanto este crê na centelha da sublevação revolucionária, portanto, a favor da redenção e contra o triunfo do fascismo, o autor aposta que o "(...) momento de perigo supremo apresenta-se uma constelação salvadora que liga o presente ao passado. Um passado em que brilha, apesar de rumo, na sombra da noite do fascismo triunfante, a estrela da esperança, a estrela messiânica da redenção".( LOWY, 2005,p.68). A ENFF do MST é esta estrela da esperança, uma vez que concebe tal processo de articular historicamente o passado à luz dos dilemas existenciais do presente também através da redenção dos vencidos. Sobretudo, através daquilo que segundo o MST é designado como sendo a mística:

A mística deve ser entendida como sendo o conjunto de motivações que sentimos no dia-a-dia, no trabalho organizativo, que impulsiona nossa luta para frente. Ela é responsável por reduzir a distância entre o presente e o futuro, fazendo-nos viver antecipadamente os objetivos que definimos e queremos alcançar. (MST, 1991)

\footnotetext{
21 "Não é que o passado lança sua luz sobre o presente ou que o presente lança sua luz sobre o passado; mas a imagem é aquilo em que o ocorrido encontra o agora num lampejo, formando uma constelação. Em outras palavras: a imagem é a dialética na imobilidade. Pois, enquanto a relação do presente com o passado é puramente temporal e contínua, a relação do ocorrido com o agora é dialética - não é uma progressão, e sim uma imagem, que salta (...)" (BENJAMIN, Passagens, [N 2a, 3], p.504).

22 As cronologias históricas estão atravessadas em seu íntimo pelas dimensões éticas e políticas do pesquisador. De maneira que a divisão do tempo insere-se nas tensas relações de poder historicamente constituídas, jamais - axiologicamente falando- imparcial, neutra e objetiva. Como exemplo do caráter ético da escolhas epistêmicas do sujeito-pesquisador, temos a clássica divisão do "breve século XX" do historiador Eric Hobsbawm, a saber: ele- o século passado- começa com a vitória conquista bolchevique sobre o Czar, a épica Revolução Russa(1917), e termina com a queda do Muro de Berlim em virtude do colapso da URSS(1991), o chamado fim do socialismo "real". Um século, pois, à sua moda, não tem cem anos, mas atende as preocupações epistemológicas de nosso ser-estar no mundo.
} 
A mística tem íntimas relações com esse belo e digno trabalho de re-memorar os combatentes do passado tanto no quotidiano quanto mediante momentos fundamentais da militância política, tais como: marchas, ocupações, performances musicais e poéticas, inaugurações de monumentos, seminários, palestras, cursos e afins. Sendo um importantíssimo instrumento da luta política e simbólica, a mística está umbilicalmente vinculado à própria historicidade de autoformação do Movimento, pois

\footnotetext{
a mística está presente em todos os espaços, sejam falados, escritos, cantados, representados; por exemplo, os desenhos e as fotos nos cadernos de formação. (...) é algo dinâmico que transcende as tentativas de elaborações de conceitos, porque está diretamente relacionada á concepção dialética do mundo, de homem e de sociedade, como também á religiosidade de seus membros, e a influência da Igreja no processo organizativo. (MAIA,2008)
}

A mística do MST re-estabelece uma relação mágica com o cosmo, o qual tece uma ritualística com as experiências humanas e o meio ambiente:

\begin{abstract}
Em Rua de mão única (1928), Benjamin se refere à embriaguez como expressão da relação mágica do homem antigo com o cosmos, mas dá a entender que a experiência (Erfahrung) do Rausch que caracterizava essa relação ritual com o mundo desapareceu da sociedade moderna. Ora, no ensaio de 1929, ele parece tê-la reencontrado, sob nova forma, no surrealismo. (LOWY, 2016)
\end{abstract}

O capitalismo é desencantado, na medida em que destrói progressiva- mente todos os elos mágicos e ritualísticos do homem com o cosmo, posto que ele próprio encontra-se numa castradora jaula de ferro, para usar a acepção de Max Weber acerca do encarceramento social entabulado pela lógica mercantil vigente. A reflexão problematizadora sobre as relações materiais e espirituais da existência constitui, a um só tempo, alicerce para compreender as contradições ontológicas da sociedade do capital, como para sonhar/ construir efetivamente outro mundo possível.

No que tange ao contexto de cerceamento das liberdades, a fantasia (elemento essencial da mística) é umas das primeiras da lista posta em achincalhe pela libido repressora do colapso a vapor da máquina capitalista, na qual o sonho, a imaginação e a magia perdem sua massa revolucionária (tal qual era pensada no Surrealismo), para atender aos anseios do consumo imediato e compulsório de mercadorias. O MST procura na mística trazer a cena esses elementos do cor-ação. Urge operar tal redefinição categórica, tanto porque há uma devoção universal aos valores egoístas da assassina burguesia, quanto pelo inquestionável fato que a miséria e a fome só aumentam em relação inversamente proporcional a riqueza dos mais ricos. Sem dúvida, a prática da mística do MST é recurso ontológico para ensejar mudanças nas mentes, nos espíritos e corações. 


\section{Considerações finais ou um Brinde: Uma breve cena da Mística ${ }^{23}$}

Os apresentadores- atores gritam: -Internacionalizemos a luta!. Internacionalizemos a esperança!. O público-ator responde em uníssono à semelhança de um jogral:- Internacionalizemos a luta!. Internacionalizemos a esperança!. Apresentadores esbravejam: - Pátria livre, venceremos! O público-ator, retruca: - Pátria livre, venceremos! Enquanto se Canta a Internacional Comunista , as bandeiras do MST e da Via Campesina são hasteadas. Após consagrada ao cume, a bandeira tremula ao som da máxima de Marx e Engels enquanto todos e todas bradam a palavra de ordem: 'trabalhadores do mundo inteiro,uni-vos'!, 'trabalhadores do mundo inteiro,uni-vos!', 'trabalhadores do mundo inteiro,uni-vos!'. Salva de palmas. Demasiado singelo? Não para minha alma de sonhar-te, não para o meu corpo que apreendeu com o poeta o encanto que reside nas profundezas do ínfimo, entendendo como as coisas pequeninas tornam-se imensas através de um olhar desperto. Meu coração se enche de tenacidade e alegria só de relembrar nosso contato com a extraordinária encantaria revolucionária da ENFF, pois essa é, de longe, a Escola mais linda que os olhos de minhas retinas tão fatigadas já fitaram. Sua beleza reside fundamentalmente em dois motivos: primeiramente, pelo esplendor da natureza que ali se presenteia, seja na disposição paisagística com suas flores e árvores nativas da Mata Atlântica que honraria o melhor monumento modernista de Roberto Burle Marx, seja pelo vôo triunfal dos passarinhos( araras, periquito-rei, curió, canaleiro de chapéu-preto, carcará, bem-te-vi amarelo, bacurau, entre outros tantos não identificáveis em nossos escassos conhecimentos ornitológicos) que ali sobrevoam para deleite espiritual de seus amantes observadores. Como é belo ver o afeto do MST à Mãe Natureza, zelando pela manutenção das árvores nativas, preservando a paisagem natural de fauna e flora preexistentes, onde a passarada canta com alegria e os arvoredos exibem seu resplendor. Confesso que vi e vivi a escola mais linda do Brasil, quiçá, do mundo!

Sua segunda boniteza é a coragem de lutar, essa bela disposição moral de prosseguir adiante na perspectiva de transformação radical da sociedade, sobretudo, por apresentar um projeto consoante com os valores de formação da autoeducação dos trabalhadores baseado no desenvolvimento contínuo da consciência socialista. Assim, o poder místico e vibrante da ENFF atua poderosamente na vida, no amor, na carne e no espírito de centena de milhares de lutadores pobres que não sucumbem diante da tirânica fúria dos sanguinários capitalistas, já que lutam ardorosamente por justiça social e por um projeto popular de Nação. Ao potencializar ao máximo a formação de quadros para avançar num projeto de unidade da classe trabalhadora, contribui sobremaneira tanto no fortalecimento dos laços de solidariedade de classe, quanto ajuda no desenvolvimento contínuo da consciência socialista, alicerce para a construção de uma ordem societária hegemônica alternativa. Nesta conformidade redentora, Walter Benjamim é companheiro super bemvindo para a peleja, já que deu-se em holocausto para que prosseguíssemos na luta contra o fascismo.

\footnotetext{
23 “(...) Ela é a motivação que nos faz viver a causa até o fim. È aquela energia que temos e que não nos deixa dizer não, quando nos solicitamos ajuda. È a vontade de estar em todos os lugares ao mesmo tempo, de querer ajudar e realizar coisas que fazem a luta ser vitoriosa. (...) A mística é fundamental para a vida e para a luta. Sem mística na vida cotidiana perdemos a alegria, a vibração, o interesse e a motivação de vive. Sem mística na luta, perdemos a vontade, a combatividade, a criatividade e o amor pela causa. Neste sentido, a mística se expressa de muitas maneiras. Cada militante, homem ou mulher dão de si, aquilo que possuem como carisma, talentos ou habilidades, cooperando e oferecendo-se como elementos centrais do programa, sendo a parte física e mental da tática e da estratégia do programa. (...) a mística é a procura de explicações e ao mesmo tempo o incentivo para viver o inexplicável. BOGO, Ademar. $A$ mística: parte da vida $\boldsymbol{e}$ da luta. Extraído em: http://base.dph.info/pt/fiches/dph/fiche-dph-8237.html . Acessado em: 26.05.2019
} 


\section{Referências bibliográficas}

ALBUQUERQUE, Gerson Rodrigues de. História e historiografia do Acre: Notas sobre os silêncios e a lógica do progresso. Tropos: comunicação, sociedade e cultura, Rio Branco, AC, v. 1, n. 4, 7 dez. 2015.

ANDRADE, A Rosa do Povo. 21. ed. Rio de Janeiro: Record, 2000.

BENJAMIN, Walter. Obras escolhidas: Magia e técnica, arte e política. Ensaios sobre literatura e história da cultura. Tradução: Sérgio Paulo Rouanet. São Paulo: Brasiliense, 1987. v. 1.

. Escritos sobre mito e linguagem. Trad. Susana Kampff e Ernani Chaves. São Paulo: Duas Cidades; Ed. 34, 2011.

. Origem do drama trágico alemão. Tradução: João Barrento. 2. ed. Belo Horizonte: Autêntica, 2013.

. Magia e técnica, arte e política: ensaios sobre literatura e história da cultura. Trad. Sérgio Paulo Rouanet. 7. ed. São Paulo: Brasiliense, 2012.

UFMG, 2006.

BENJAMIN, Walter. Passagens. Tradução: Irene Aron. Belo Horizonte: Editora

BOGO, Ademar. A mística: parte da vida e da luta. Disponível em:

<http://base.dph.info/pt/fiches/dph/fiche-dph-8237.html> Acesso em: 11 nov. 2019.

COELHO, Fabiano. A Prática da Mística e a Luta pela Terra no MST. 2010. $284 \mathrm{f}$. Dissertação (Mestrado em História) - Programa de Pós-Graduação em História da faculdade de Ciências Humanas, Universidade Federal da Grande Dourados, Dourados, 2010. Disponível em:

$<$ http://www.reformaagrariaemdados.org.br/biblioteca/disserta

\%C3\%A7\%C3\%A3o-e-tese/mestrado-pr\%C3\%A1tica-da-m\%C3\%Adstica-e-luta-pela-

terra-no-mst> Acesso em: 15 nov. 2019

ENFF. Agenda 2015: 10 anos ENFF (2005-2015).

FERNANDES, Bernardo M.; STEDILE, João P. Brava Gente: a trajetória do MST e a luta pela terra no Brasil. 3. ed. São Paulo: Editora Fundação Perseu Abramo, 2005.

FUNARI, Pedro Paulo A. Considerações em torno das "teses sobre Filosofia da história", de Walter Benjamin. CRÍTICA MARXISTA .p.47 .Disponível em"

https://www.ifch.unicamp.br/criticamarxista/arquivos_biblioteca/3_PPFunari.pdf

LÖWY, Michael. "A contrapelo": A concepção dialética da cultura nas teses de Walter Benjamin (1940). Lutas Sociais, São Paulo, n. 25/26, p. 20-28, 2. sem. 2010 e 1 sem. 2011, 2011. Disponível em:

<http://www4.pucsp.br/neils/downloads/Vol.2526/michael-lowy.pdf>. Acesso em: 15 nov. 2019.

- Walter Benjamin e o Surrealismo: As núpcias químicas de dois materialismos.

Revista Limiar, São Paulo, v. 3, ed. 6, p. 54-61, 2. sem. 2016.

Disponível em: 
<https://pe riodicos.unifesp.br/index.php/limiar/article/view/9480/6938>. Acesso em: 17 set. 2019.

Por um marxismo crítico. Lutas Sociais, São Paulo, ed. 3, p. 21-30, 1997. Disponível em: <https://revistas.pucsp.br/ls/article/view/18981/pdf>. Acesso em: 12 nov. 2019.

. Walter Benjamin: aviso de incêndio: uma leitura das teses "Sobre o conceito de historia". Tradução: Wanda Nogueira Caldeira Brant. São Paulo: Boitempo, 2005. 160 p.

. A teoria da revolução no jovem Marx. Tradução: Anderson Gonçalves. São Paulo: Boitempo, 2012. 224 p.

MAIA, Luciola Andrade. Mística, educação e resistência do Movimento dos Sem Terra. Fortaleza: Edições UFC, 2008.

MARX, Karl. Crítica da filosofia do Direito de Hegel - [2.ed revista]. - São Paulo : Boitempo, 2010.

MÉSZÁROS, István. 0 desafio e o fardo do tempo histórico. São Paulo: Boitempo, 2007.

MST. A Questão da Mística no MST. [S. l.: s. n.], 1991.

SANTOS NETO, Arthur Bispo dos. A interpretação alegórica do mundo na filosofia de Walter Benjamim. Maceió: UFAL, 2007.

THOMPSON, E. P. A formação da classe operária inglesa: A árvore da liberdade. 2. ed. Rio de Janeiro: Paz e terra, 1987. v. 1. 